\title{
Effect of Jatropha curcas Seed Cake on Soil Health Parameters and Growth of Wheat Plant (Triticum aestivum L.) Grown In Sandy and Calcareous Soils
}

\author{
Azza Massoud, ${ }^{1}$ Essam Koreish, ${ }^{1}$ Mohamed Rashad, ${ }^{2}$ Mahrous Kandil ${ }^{1}$
}

\begin{abstract}
Jatropha curcas seed cake (J.S.C.) is a useful organic byproduct containing considerable amounts of nitrogen, phosphrous, potassium and micronutrients. It can be considered as a green economy soil amendment. Jatropha curcas seed cake was used as an attempt to enhance soil health and to sustain soil productivity. The objective of this study, therefore, was to investigate the effects of Jatropha curcas seed cake (J.S.C.) as an organic fertilizer and NPK as chemical fertilizers on the health parameters of sandy and calcareous soils cultivated with wheat (Triticum aestivum $\mathrm{L}$.). The results indicated that the percentages of $\mathrm{N}, \mathrm{P}$ and $\mathrm{K}$ in J.S.C. were $2.63 \%, 0.23 \%$ and $3.1 \%$ respectively. The results assured that application of the organic fertilizer (J.S.C.) and chemical fertilizers (NPK) had positively affected soil health parameters. Using organic and chemical fertilizers decresed bulk density of sandy and calcereous soils compared with the control treatment. And increased aggregate stability index. Soil organic carbon was increased by using Jatropha seed cake as organic fertilizer. In addition, the differences in dehydrogenase activity were highly significant when combined with different levels of organic and chemical fertilization with the two used soils. The soil $\mathrm{pH}$ decreased as the levels of Jatropha seed cake increased, while the EC was increased. The increasing application of jatropha seed cake and mineral fertilization increased the concentration of macro and micronutrients in plant and soil. The results indicated that the decomposition of jatropha seed cake is a microbiological process, which release inorganic forms of nutrients ( $N$, $P$ and $K$ ). It is also that addition of jatropha seed cake to sandy and calcareous soils positively affected the physical, chemical and biological indicators of the soil health.
\end{abstract}

Key words: Jatropha curcas seed cake, Soil health, Wheat, Organic fertilizer

\section{INTRODUCTION}

Jatropha curcas is a multipurpose tree, which has a potential as an alternative source for biodiesel. All of its parts can be used for human food, animal feed, fertilizer, fuel and traditional medicine (Donlaporn and Worapot. 2011). Jatropha curcas seed cake (J.S.C.) is a low-value by-product obtained after oil extraction during the preparation of biodiesel production. Increasing Jatropha curcas production as a biofuel source will increase the quantity of its seed cake. The seed cake left after extraction of oil provides high amounts of protein and essential amino acids. It containes also up to $58 \%$ of crude protein by weight and the percentages of nitrogen $(\mathrm{N})$, phosphorous $(\mathrm{P})$, and potassium $(\mathrm{K})$ contents are in the range: $3.2-4.5 \%, 1.4-2.1 \%$, and $1.2-1.7 \%$, respectively (Achten et al., 2008). The presences of these elements are recognized as nutrients sources that are even higher than that of chicken or cow manure (Achten et al., 2008). Moreover, J.S.C. contains also primary and secondary elements required for plant growth such as trace amounts of calcium, magnesium, sulphur, zinc, iron, copper, manganese and sodium (Saetae et al., 2011). One tonne of J.S.C. contains approximately $51 \mathrm{~kg}$ nitrogen, $18 \mathrm{~kg}$ phosphorus and 13 $\mathrm{kg}$ potassium, which is equivalent to $153 \mathrm{~kg} \mathrm{NPK}$ industrial fertilizer having the composition ratio of $15: 15: 15$, based on nitrogen content in presscake(Gubitz et al .,1999).

Once the oil was extracted, about 50 percent of the original seed weight remains as seed cake residue, mainly in the form of protein and carbohydrates. The amount of oil left in the seed cake depends on the extraction process. There are trade-offs for the seed cake. It may be used as a fertilizer, fuel and if it is detoxified and of non-toxic varieties, it can be used as animal fodder. The J.S.C. is high in protein (58.1 percent by weight) compared to soy meal's (48 percent) and, therefore, would be a valuable livestock protein feed supplement (Gubitz et al .,1999).

Soil health is the result of continuous conservation processes and represents the continued capacity of soil to function as a vital living ecosystem. A unique balance of chemical, physical and biological components contributes to maintaine soil health. Evaluation of soil health, therefore, requires indicators for all these components (Canstanza et al., 1992).

${ }^{1}$ Faculty of Agriculture, Alexandria University, El-Shatbi,

Alexandria, Egypt. E-mail: azzakassem82@gmail.com

essamkoreish@yahoo.com

mahrouskan@yahoo.com

${ }^{2}$ Arid Lands Cultivation Research Institute, City for Scientific

Research and Technological Applications, New Borg El Arab,

Postal Code: 21934, Alexandria, Egypt.

Email: marashad2@gmail.com,

Received July 2, 2017, Accepted August 16, 2017. 
Microorganisms appear to be excellent indicators of soil health because they respond quickly to changes in the soil ecosystem and have intimate relations with their surroundings due to their high surface / volume ratio. In some instances, changes in microbial populations or activity can precede detectable changes in soil physical and chemical properties, thereby providing an early sign of soil improvement or an early warning of soil degradation. Since microorganisms are involved in many soil processes, they may also give an integrated measure of soil health, which is considered an aspect that cannot be obtained with physical/chemical measures alone (Karlen and Stott., 1994).

Since, Jatropha, curcas seed cake is a useful organic byproduct, it can be considered as a green economy soil amendment. Thus, JSC was used as an attempt to enhance soil health and sustain its productivity. The specific objective of the present study, therefore, was to investigate the effects of JSC (organic fertilizer) and NPK (chemical fertilizer) on the health parameters of sandy and calcareous soils cultivated with wheat.

\section{MATERIALS AND METHODS}

Seeds of Jatropha (Jatropha curcas) were obtained from the Arid Lands Cultivation Research Institute, City of Scientific Research and Technological Applications, New Borg El-Arab City, Alexandria Governorate, Egypt. (www.jatromed.aua.gr).

\section{Jatropha seed cake (J.S.C.) characteristics}

Samples of J.S.C after oil extraction the seed with Soxlet, were analyzed for total nitrogen, potassium and phosphorus by the methods outlined by Page et al., (1982).

The amount of soil organic carbon was determined by wet-oxidation method according to Walkley-Black (Page et al., 1982). And these of available micronutrients were determined according the method described by Jones et al. (1991).

\section{Soil characteristics}

Two soil types were used in this study; the first one is sandy soil, which is collected from El Omayed at the Nothern Western Coast of Egypt, Alxandaria city, and the second soil is calcareous, which is collected from the experimental farm of the City of Scientific Research and Technological Applications, New Borg El-Arab City, Alexandria city, Egypt. The soil samples were collected from a depth of 0-30 cm, air - dried ground and passed through $2 \mathrm{~mm}$ sieve and stored in plastic bags for experimental study and analyses. The particle size distribution of the soil was measured by hydrometer method (FAO., 1974). Soil pH and electrical conductivity (EC) were measured in soil paste extracts according to Page et al. (1982). Total carbonate was determined by calcimeter method (Nelson and Winter., 1982). Soil organic carbon was determined by wetoxidation according to Walkley-Black method (Page et al., 1982). The amounts of available Nitrogen, phosphorous and potassium were determined by standard the methods outlined by Page et al. (1982) and the amount of available micronutrients were extracted by DTPA reagent (Soltanpour and Schwab., 1997) and measured by Varian atomic absorption spectrophotometer (AAS). Table (1) represents the main soil characteristics of the studied soils.

Table 1. The main characteristics of the studied soil

\begin{tabular}{|c|c|c|}
\hline Soil characteristics & $\begin{array}{c}\text { Sandy } \\
\text { soil }\end{array}$ & $\begin{array}{c}\text { Calcareous } \\
\text { soil }\end{array}$ \\
\hline $\mathrm{pH}^{*}$ & 8.2 & 8.6 \\
\hline $\mathrm{EC}^{*}\left(\mathrm{dSm}^{-1}\right)$ & 1.1 & 3.2 \\
\hline $\mathrm{CO}_{3}^{--}(\%)$ & 18.6 & 26.5 \\
\hline $\mathrm{OC}(\%)$ & 0.26 & 1.28 \\
\hline \multicolumn{3}{|c|}{ Particle size distribution $(\%)$} \\
\hline Sand & 83.8 & 39.6 \\
\hline Silt & 5.2 & 5.2 \\
\hline Clay & 11.0 & 55.2 \\
\hline Soil texture & $\begin{array}{l}\text { Loamy } \\
\text { sand }\end{array}$ & $\begin{array}{c}\text { Sandy clay } \\
\text { loam }\end{array}$ \\
\hline \multicolumn{3}{|c|}{ Available nutrients $\left(\mathrm{mg} \mathrm{Kg}^{-1}\right)$} \\
\hline $\mathrm{N}$ & 83.2 & 157.4 \\
\hline $\mathrm{P}$ & 13.3 & 13.8 \\
\hline K & 109.2 & 281.2 \\
\hline $\mathrm{Cu}$ & 1.9 & 2.8 \\
\hline $\mathrm{Fe}$ & 15.7 & 11.6 \\
\hline $\mathrm{Mn}$ & 5.7 & 4.9 \\
\hline $\mathrm{Zn}$ & 3.4 & 3.6 \\
\hline
\end{tabular}

*Saturated soil paste extract.

\section{Greenhouse Experiment}

Seeds of Wheat (Triticum aestivum L cv. Gemmiza 10) were sown in a pot containing $5 \mathrm{~kg}$ soil (sandy or calcareous) with different application rates of J.S.C. The seedlings were thinned to 5 seedlings per pot (After 20 days from seed sowing) and irrigation water was added to bring the soil moisture to $60 \%$ of field capacity. Plants were harvested after 10 weeks from seed sowing. The growth was from Nov. 30-2014 to April 8-2015. The plants were fertilized with organic fertilizer represented by J.S.C. and mineral fertilization (N (Ammonium nitrate, 33.5\%), P (Mono superphosphate, $15 \%)$ and $\mathrm{K}($ Potassium sulphate, 48\%)). The experimental treatments are shown in Table 2.

After harvest, the soil samples (sandy and calcareous) were collected and analyzed for soil health parameters and plants were analyzed for yield productivity. 
Table 2. Treatment of organic fertilizer (J.S.C) and mineral fertilizers (N(Ammonium nitrate ,33.5\%), $\mathbf{P}($ Mono superphosphate, $15 \%)$ and $\mathrm{K}($ Potassium sulphate , $48 \%$ )) to the studied soils

\begin{tabular}{ccc}
\hline Soil Type & $\begin{array}{c}\text { J.S.C. Levels of } \\
\text { recommended } \\
\text { dose (\%) }\end{array}$ & $\begin{array}{c}\text { NPK Levels of } \\
\text { recommended } \\
\text { dose (\%) }\end{array}$ \\
\hline Sandy/ & 0 & 0 \\
Calcareous & & 50 \\
& & 100 \\
\cline { 2 - 3 } & 25 & 0 \\
& 50 \\
& 50 & 100 \\
\hline & & 0 \\
& & 50 \\
& 75 & 100 \\
\hline & & 0 \\
& & 100 \\
\hline 100 & 0 \\
& & 50 \\
& & 100 \\
\hline
\end{tabular}

Soil health parameters:

Soil health parameters are classified as follows:

Physical parameters: The aggregate stability index (SI) and bulk density (for soil samples under different treatments) were determined using the methods outlined by Kemper and Rosenau, (1986).

Chemical parameter: The $\mathrm{pH}$ and electrical conductivity (EC) were also measured according to Page et al. (1982). The amount of available nitrogen, phosphorous and potassium were determined by standard methods according to Page et al. (1982) and those of micronutrients were extracted by DTPA (Soltanpour and Schwab., 1997) and measured by AAS.

biological parameter: Dehydrogenase activity was determined by triphenyltetrazolium chloride (TTC) as described by Casida et al. (1964).Soil organic carbon was determined by wet-oxidation according to WalkleyBlack method (Page et al., 1982).

\section{Yield Parameters:}

Spike measurements: number of 100 grains $/ 5$ plants, spike weight, grain weight and plant dry weight were measured. Harvest index was calculated according to the following equation:

Harvest index $(\mathrm{HI})=$ grain weight $/$ plant dry weight

Sample of plants were analyzed for total nitrogen, potassium and phosphorus by the methods outlined by Page et al.(1982) and these of available micronutrients were determined according to the method described by Jones et al. (1991).

\section{Statistical analysis}

The experimental data were processed using SAS Software (SAS Institute, 2007).

The experiment was arranged in split -split plot designs with three replicates.

\section{RERSULTS AND DISCUSSION}

\section{Jatropha seed cake characteristics}

Elemental composition: Table (3) indicated that the J.S.C. is a material of a very high nitrogen and carbon content. The percentages of nitrogen, phosphorous and potassium contents were $2.63 \%, 0.23 \%$ and $3.1 \%$ respectively in J.S.C. These elements are recognized as the organic nutrients sources that are even higher than that of chicken and cow manures (Achten et al., 2008). It containes a amixture of primary and secondary elements which are required for plant growth.

Table 3. The main elemental composition of of jatropha seed cake (J.S.C.)

\begin{tabular}{ll}
\hline Element & Value \\
\hline $\mathrm{N}(\%)$ & $2.60-2.66$ \\
$\mathrm{P}(\%)$ & $0.21-0.25$ \\
$\mathrm{~K}(\%)$ & $3.0-3.2$ \\
$\mathrm{OC}(\%)$ & $7.70-7.86$ \\
$\mathrm{Cu}\left(\mathrm{mg} \mathrm{kg}^{-1}\right)$ & $24-28$ \\
$\mathrm{Fe}\left(\mathrm{m} \mathrm{kg} \mathrm{k}^{-1}\right)$ & $700-710$ \\
$\mathrm{Mn}\left(\mathrm{mg} \mathrm{kg}^{-1}\right)$ & $165-175$ \\
$\mathrm{Zn}\left(\mathrm{mg} \mathrm{kg}^{-1}\right)$ & $49.0-49.2$ \\
\hline
\end{tabular}

Soil physical parameters: Table (4) revealed that the differences in the bulk density between the two studied soils (sandy and calcareous) are highly significant. These high significant differences are logic and can be attributed to the differences between the origins of the two soils. Also, the obtained results showed that the differences in the values of bulk density with different levels of J.S.C. are not significant for each soil type. The use of different levels of J.S.C. for each soil is highly significant. In regard to application of mineral and organic fertilizers, differences in bulk densities when using different levels of mineral fertilization were insignificant. Also, when using either two different types of soils, the differences were not significant, but when using different levels of mineral fertilization of the different types of soils the difference in bulk density was significant. The differences in aggregate stability (SI) were highly significant after application of all treatments to the two studied soils. Alves (2001) stated that the influence of organic matter on soil aggregation is a dynamic process. Jastrow et al. (1998) stated that the presence of stable aggregates enhances the soil ability to store water, reducing the loss of particles and nutrients by erosion and facilitates the physical protection and accumulation of soil organic matter. 
Table 4. Effect of chemical (NPK) and organic fertilizaters on bulk density and stability index of sandy and calcareous soils

\begin{tabular}{cccccc}
\hline NPK Levels & J. S. C. & \multicolumn{2}{c}{ Bulk Density $\mathbf{( g / \mathbf { c m } ^ { 3 } )}$} & \multicolumn{2}{c}{ Stability Index } \\
\cline { 2 - 6 } & Levels (\%) & Sandy soil & calcareous soil & Sandy soil & Calcareous soil \\
\hline & 0 & 1.61 & 1.20 & 0.21 & 0.66 \\
& 25 & 1.74 & 1.28 & 0.14 & 0.80 \\
0 & 50 & 1.61 & 1.20 & 0.24 & 0.83 \\
& 75 & 1.72 & 1.31 & 0.51 & 0.83 \\
& 100 & 1.64 & 1.36 & 0.44 & 0.93 \\
\hline & 0 & 1.72 & 1.29 & 0.19 & 0.64 \\
& 25 & 1.62 & 1.15 & 0.55 & 0.84 \\
& 50 & 1.67 & 1.24 & 0.57 & 0.83 \\
& 75 & 1.62 & 1.38 & 0.62 & 0.84 \\
& 100 & 1.49 & 1.15 & 0.62 & 0.87 \\
\hline 0 & 0 & 1.60 & 1.41 & 0.05 & 0.88 \\
& 25 & 1.66 & 1.41 & 0.58 & 0.20 \\
& 50 & 1.62 & 1.32 & 0.50 & 0.25 \\
\hline LSD 00 05 & 75 & 1.52 & 1.43 & 0.63 & 0.60 \\
& 100 & 1.59 & 1.23 & 0.64 & 0.70 \\
\hline
\end{tabular}

\section{Soil biological parameters}

Table (5) revealed that there were significant differences in organic carbon contents in soil between all treatments, and also significant differences were recorded when using different levels of J.S.C. and mineral fertilizers. Fortuna et al. (2003) argued that organic matter amendment could increase the carbon contents in soils up to $45 \mathrm{~g} \cdot \mathrm{kg}^{-1}$. The use of organic fertilizer (J.S.C) increased soil organic carbon contents. Soil structure, In addition, the differences in dehydrogenase activity were highly significant when combined with different levels of mineral fertilizer or only mineral fertilizer with different levels using two different soil types. Also, according to the results of other researchers (Scherer et al. (2011), and Liang et al. (2014)), in soils treated with farmyard manure ; the dehydrogenase activity is increasing. Our results are in the same direction with the findings of Watts et al. (2010) and Scherer et al. (2011) which proposed that the treatments with high organic amendments might exhibit the greatest dehydrogenase activity.

Table 5. Effect of addition of chemical (NPK) and organic fertilizers on OC and dehydrogenase activity of sandy and calcareous soils

\begin{tabular}{|c|c|c|c|c|c|}
\hline \multirow{2}{*}{$\begin{array}{c}\text { N P K } \\
\text { Levels (\%) }\end{array}$} & \multirow{2}{*}{$\begin{array}{c}\text { J. S. C. } \\
\text { Levels (\%) }\end{array}$} & \multicolumn{2}{|c|}{ OC $(\%)$} & \multicolumn{2}{|c|}{ Dehydrogenase $\left(\mu \mathrm{g}\right.$ TPF $\left.\mathrm{ml}^{-1}\right)$} \\
\hline & & Sandy soil & Calcareous soil & Sandy soil & Calcareous soil \\
\hline \multirow{5}{*}{0} & 0 & 0.24 & 1.27 & 200.75 & 366.21 \\
\hline & 25 & 0.26 & 1.49 & 212.80 & 318.02 \\
\hline & 50 & 0.32 & 1.52 & 265.81 & 316.41 \\
\hline & 75 & 0.35 & 1.53 & 73.04 & 666.61 \\
\hline & 100 & 0.34 & 1.57 & 80.27 & 563.80 \\
\hline \multirow[b]{5}{*}{50} & 0 & 0.27 & 1.53 & 83.48 & 438.50 \\
\hline & 25 & 0.39 & 1.58 & 68.22 & 621.63 \\
\hline & 50 & 0.36 & 1.55 & 51.35 & 535.69 \\
\hline & 75 & 0.38 & 1.48 & 301.95 & 589.50 \\
\hline & 100 & 0.47 & 1.74 & 318.82 & 397.53 \\
\hline \multirow[b]{5}{*}{100} & 0 & 0.37 & 1.58 & 128.46 & 431.27 \\
\hline & 25 & 0.30 & 1.62 & 207.98 & 507.57 \\
\hline & 50 & 0.34 & 1.63 & 109.18 & 499.54 \\
\hline & 75 & 0.39 & 1.69 & 104.36 & 450.55 \\
\hline & 100 & 0.45 & 1.60 & 287.49 & 365.41 \\
\hline \multicolumn{2}{|c|}{ LSD 0.05} & \multicolumn{2}{|c|}{0.15} & \multicolumn{2}{|c|}{3.80} \\
\hline
\end{tabular}




\section{Soil chemical parameters}

The effect of chemical (NPK) and organic (J.S.C.) fertilization on soil $\mathrm{pH}$ and $\mathrm{EC}$ is presented in Table (6). The differences between the two soils were highly significant and this can be attributed to the origin of each soil. The results were significantly different after using various levels of J.S.C. The soil $\mathrm{pH}$ decreased as the levels of J.S.C increased. This could be due to the increase of organic matter in the soil. The obtained results confirm the finding of Walker et al. (2003) who reported that addition of compost to soil decreased soil pH. Smiciklas et al. (2002), Pattanayak et al. (2001) and Yaduvanshi (2001) observed a decrease in soil $\mathrm{pH}$ after additions of organic materials. The production of organic acids (amino acid, glycine, cystein and humic acid) during mineralization (amminization and ammonification) of organic materials by heterotrophs and nitrification by autotrophs would cause decrease in soil pH (Smiciklas et al., 2002).

Contradictory, the EC increased with increasing the levels of J.S.C in soil and this may be attributed to the increase of mineralization of organic matter in soil. Similar results have been reported in the literature (Sarwar et al., 2003; Niklasch and Joergensen, 2001), which indicated that EC increased in soils when organic materials of different natures were applied to the soil. Similar results were found by Gonzalez et al. (2010).

Table (7) showed the effects of chemical and organic fertilization on the concentrations of available $\mathrm{NH}_{4}{ }^{++}$, $\mathrm{NO}_{3}{ }^{-}, \mathrm{P}, \mathrm{K}, \mathrm{Fe}, \mathrm{Mn}$ and $\mathrm{Zn}$ in sandy and calcareous soils. Additions of different levels of J.S.C. have high significant effect on the concentractions of all elements of both two soils. This significant effect can be attributed to the mineralization of the added organic material. These results showed that addition of NPK increased the availability of the studied elements. In addition, as applied organic and mineral fertilizers are increased the availability of these elements are increased. This increase may be due to the decrease of $\mathrm{pH}$. It was reported that remarkable amount of $\mathrm{N}$ was available to the plant due to the addition of organic matter to soil (Zupanc and Zupanc., 2010).

The data obtained agree with those of who found that applying organic matter to the soil had increased the concentration of available $\mathrm{P}$ in soil (Padmavathiamma et al., 2008). It was also found that the increase of soil organic matter had increased $\mathrm{K}$ availability in soil (Olk et al., 1993). Singh et al. (2002) and Verma et al., (2005) reported that prolonged use of mineral fertilizers, manure and compost increased the potassium content in the soil.

Addition of different levels of J.S.C. had high significant effect for all elements, due to the mineralization of the added organic matter. Also, application of different levels of mineral fertilization had high significant effect on all elements.

\section{Concentrations of macro and micronutrients in plant.}

Table (8) showed that as J.S.C. and mineral fertilizers levels are increased the concentrations of nitrogen, potassium and phosphorus are significally increased in plant.

Table 6. Effect of chemical (NPK) and organic fertilizers on the pH and EC of sandy and calcareous soils

\begin{tabular}{|c|c|c|c|c|c|}
\hline \multirow{2}{*}{$\begin{array}{c}\text { NPK } \\
\text { Levels (\%) }\end{array}$} & \multirow{2}{*}{$\begin{array}{c}\text { J. S. C. } \\
\text { Levels (\%) }\end{array}$} & \multicolumn{2}{|c|}{$\overline{\mathrm{pH}}$} & \multicolumn{2}{|c|}{$\left.\mathrm{EC}(\mu \mathrm{S} \mathrm{cm})^{-1}\right)$} \\
\hline & & Sandy soil & calcareous soil & Sandy soil & Calcareous soil \\
\hline \multirow{5}{*}{0} & 0 & 7.78 & 8.18 & 741 & 1357 \\
\hline & 25 & 7.69 & 8.02 & 804 & 1417 \\
\hline & 50 & 7.57 & 7.80 & 674 & 1593 \\
\hline & 75 & 7.74 & 7.62 & 893 & 1650 \\
\hline & 100 & 7.70 & 7.55 & 866 & 1687 \\
\hline \multirow[b]{5}{*}{50} & 0 & 7.47 & 7.74 & 954 & 1783 \\
\hline & 25 & 7.49 & 7.79 & 1255 & 1913 \\
\hline & 50 & 7.43 & 7.51 & 820 & 2220 \\
\hline & 75 & 7.21 & 7.47 & 1228 & 2357 \\
\hline & 100 & 7.35 & 7.48 & 1235 & 2450 \\
\hline & 0 & 7.67 & 7.77 & 1057 & 2303 \\
\hline & 25 & 7.40 & 7.56 & 1098 & 2337 \\
\hline & 50 & 7.34 & 7.51 & 1298 & 2423 \\
\hline & 75 & 7.66 & 7.28 & 1155 & 2637 \\
\hline 100 & 100 & 7.14 & 7.61 & 1012 & 2417 \\
\hline \multicolumn{2}{|c|}{ LSD 0.05} & \multicolumn{2}{|c|}{0.30} & \multicolumn{2}{|c|}{430} \\
\hline
\end{tabular}




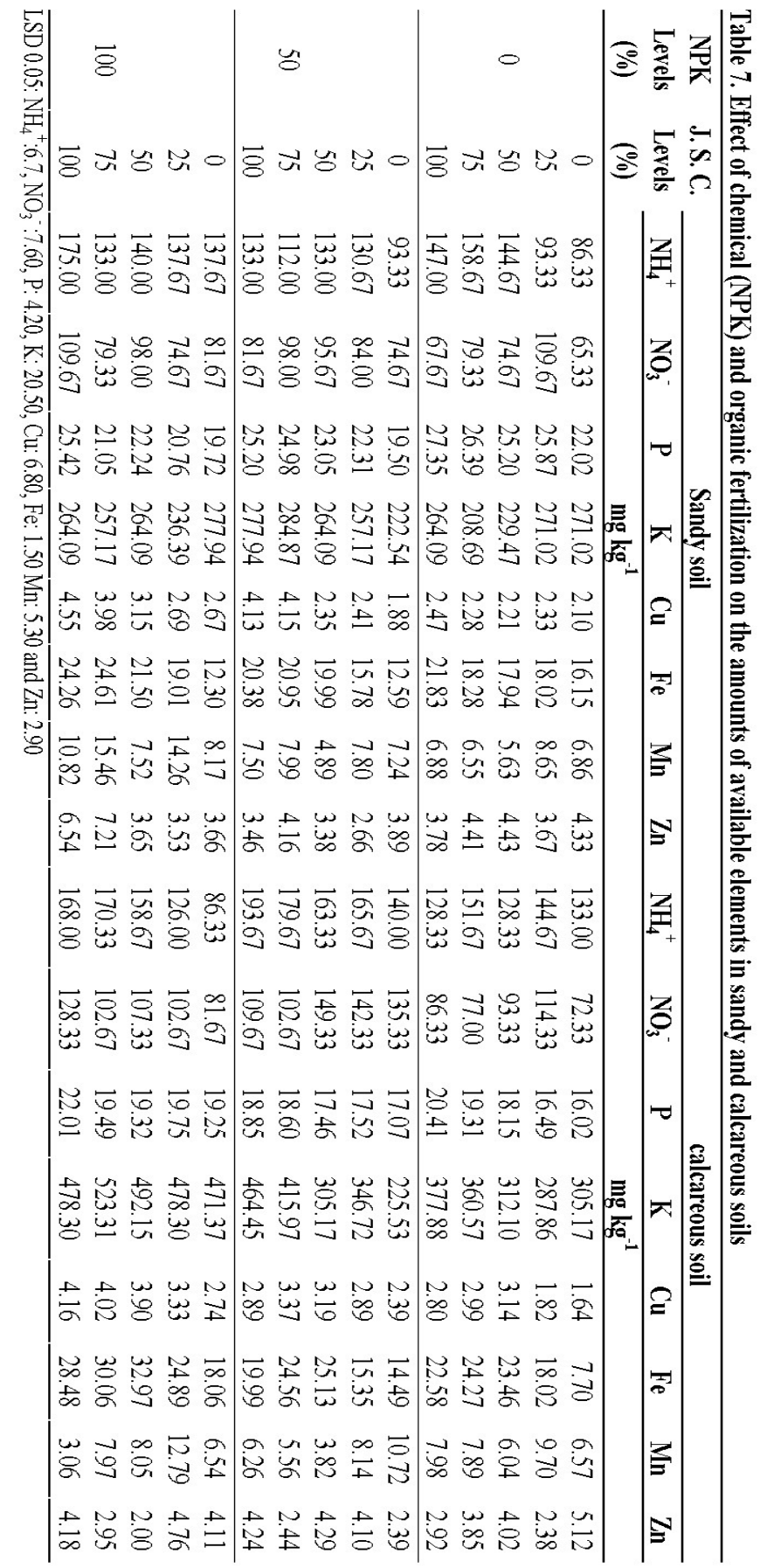


Table 8. Effect of chemical (NPK) and organic (J.S.C.) fertilization on the concentrations of macronutrients in wheat plant grown in Sandy and calcareous soils

\begin{tabular}{|c|c|c|c|c|c|c|c|}
\hline \multirow{3}{*}{$\begin{array}{c}\text { NPK } \\
\text { Levels (\%) }\end{array}$} & \multirow{3}{*}{$\begin{array}{c}\text { J. S. C. } \\
\text { Levels }(\%)\end{array}$} & \multicolumn{3}{|c|}{ Sandy soil } & \multicolumn{3}{|c|}{ Calcareous soil } \\
\hline & & $\mathbf{N}$ & $\mathbf{P}$ & $\mathbf{K}$ & $\mathbf{N}$ & $\mathbf{P}$ & $\mathbf{K}$ \\
\hline & & \multicolumn{3}{|c|}{$\%$} & \multicolumn{3}{|c|}{$\%$} \\
\hline \multirow{5}{*}{0} & 0 & 0.36 & 0.02 & 0.04 & 0.34 & 0.03 & 0.90 \\
\hline & 25 & 0.48 & 0.02 & 0.18 & 0.62 & 0.02 & 1.15 \\
\hline & 50 & 0.61 & 0.02 & 0.25 & 0.65 & 0.03 & 1.56 \\
\hline & 75 & 0.67 & 0.02 & 0.70 & 0.76 & 0.03 & 2.26 \\
\hline & 100 & 0.76 & 0.02 & 1.29 & 0.85 & 0.03 & 2.67 \\
\hline \multirow{5}{*}{50} & 0 & 0.81 & 0.02 & 0.56 & 0.99 & 0.02 & 2.67 \\
\hline & 25 & 1.07 & 0.02 & 1.46 & 1.01 & 0.03 & 3.26 \\
\hline & 50 & 1.05 & 0.03 & 2.57 & 1.05 & 0.03 & 3.50 \\
\hline & 75 & 1.04 & 0.02 & 2.60 & 1.12 & 0.03 & 4.47 \\
\hline & 100 & 1.05 & 0.11 & 2.71 & 1.17 & 0.03 & 3.36 \\
\hline \multirow{5}{*}{100} & $0 \%$ & 0.91 & 0.02 & 0.90 & 0.98 & 0.03 & 1.15 \\
\hline & 25 & 0.97 & 0.02 & 1.11 & 1.05 & 0.03 & 2.26 \\
\hline & 50 & 1.04 & 0.02 & 1.98 & 1.13 & 0.03 & 2.81 \\
\hline & 75 & 0.93 & 0.03 & 2.74 & 1.20 & 0.03 & 3.12 \\
\hline & 10 & 1.05 & 0.04 & 2.74 & 1.20 & 0.04 & 3.33 \\
\hline
\end{tabular}

LSD 0.05: N: 0.12, P: 0.01, K: 0.45

This increase of nitrogen, potassium and phosphorus may be attributed to the increase of availability of these elements in soil due to organic and mineral fertilization. The obtained results confirm the finding of Kuzyakov (2002) who reported that nitrogen, phosphorus and potassium concentrations were higher in wheat plant with the application of organic material to the soil.

The Table (9) showed that the increase of J.S.C and mineral fertilization levels significantly increased the concentration of $\mathrm{Cu}, \mathrm{Fe}, \mathrm{Mn}$ and $\mathrm{Zn}$ in plant. This increase of $\mathrm{Cu}, \mathrm{Fe}, \mathrm{Mn}$ and $\mathrm{Zn}$ in plant may be due to

Table 9. Effect of chemical (NPK) and organic fertilization on the concentrations of micronutrients in wheat plant grown in Sandy and calcareous soils

\begin{tabular}{cccccccccc}
\hline NPK & J. S. C. & \multicolumn{4}{c}{ Sandy soil } & \multicolumn{3}{c}{ Calcareous soil } \\
\cline { 2 - 9 } Levels(\%) & Levels(\%) & $\mathbf{C u}$ & Fe & Mn & Zn & Cu & Fe & Mn & Zn \\
\hline & 0 & 5.97 & 107.77 & 10.70 & 10.94 & 7.70 & 93.53 & 16.33 & 18.83 \\
& 25 & 9.90 & 111.53 & 10.43 & 13.31 & 10.27 & 140.83 & 17.23 & 23.59 \\
& 50 & 11.17 & 123.73 & 14.53 & 15.69 & 11.13 & 135.10 & 24.67 & 25.90 \\
0 & 75 & 11.47 & 118.87 & 12.67 & 16.38 & 11.30 & 149.27 & 25.33 & 26.94 \\
& 100 & 11.17 & 170.03 & 15.97 & 13.69 & 11.40 & 170.17 & 36.57 & 29.31 \\
\hline & 0 & 11.07 & 127.57 & 13.20 & 19.66 & 10.83 & 105.47 & 14.27 & 18.68 \\
& 25 & 14.53 & 122.67 & 14.60 & 24.26 & 12.40 & 116.57 & 22.43 & 25.37 \\
& 50 & 18.03 & 249.37 & 15.23 & 22.65 & 13.33 & 132.33 & 28.53 & 28.43 \\
50 & 75 & 15.30 & 175.70 & 21.40 & 23.79 & 17.47 & 132.70 & 36.33 & 42.94 \\
& 100 & 37.63 & 177.57 & 20.37 & 22.99 & 16.00 & 157.87 & 42.17 & 43.64 \\
\hline & 0 & 13.27 & 169.80 & 12.67 & 16.32 & 7.37 & 115.43 & 28.57 & 22.13 \\
& 25 & 11.10 & 180.13 & 15.93 & 19.10 & 12.40 & 128.50 & 25.33 & 27.22 \\
& 50 & 17.13 & 224.50 & 20.90 & 22.80 & 15.90 & 152.80 & 29.20 & 29.62 \\
& 75 & 25.10 & 232.43 & 20.90 & 25.15 & 18.50 & 155.50 & 45.53 & 32.49 \\
& 100 & 43.93 & 226.87 & 21.97 & 31.52 & 24.47 & 167.07 & 51.73 & 40.00 \\
\hline
\end{tabular}

LSD 0.05: $\mathrm{Cu}: 7.30, \mathrm{Fe}: 45.10, \mathrm{Mn}: 4.30, \mathrm{Zn}: 6.80$ the increase the availability of these elements in soil as a result of application of organic and mineral fertilizers.

\section{Yield Parameters}

Table (10) showed that the increase of J.S.C. and mineral fertilization levels increased the dry weight, spike weight, seed weight, weight of 100 seeds and HI compared with the control. This increase of the studied parameter was significant with the two studied soils under different levels of J.S.C. and NPK mineral fertilization. 
Azza Massoud, Essam Koreish,.et al.,: Effect of Jatropha Curcas Seed Cake on Soil Health Parameters and Growth ...

Table 10. Effect of chemical (NPK) and organic (J.S.C.) fertilization on some plant growth properties of wheat grown in Sandy and calcareous soils

\begin{tabular}{|c|c|c|c|c|c|c|c|c|c|c|c|}
\hline \multirow[b]{2}{*}{$\begin{array}{c}\mathbf{N}, \mathbf{P}, \mathbf{K} \\
\text { Levels } \\
(\%)\end{array}$} & \multirow[b]{2}{*}{$\begin{array}{c}\text { J. S.C } \\
\text { levels } \\
(\%)\end{array}$} & \multicolumn{5}{|c|}{ Sandy soil } & \multicolumn{5}{|c|}{ Calcareous soil } \\
\hline & & $\begin{array}{c}\text { dry } \\
\text { weight } \\
\text { gm } \\
\end{array}$ & $\begin{array}{c}\text { spike } \\
\text { weight } \\
\text { gm } \\
\end{array}$ & $\begin{array}{c}\text { seed } \\
\text { weight } \\
\text { gm } \\
\end{array}$ & $\begin{array}{c}\text { weight } \\
\text { of } 100 \\
\text { seed }\end{array}$ & $\begin{array}{l}\mathrm{HI} \\
\%\end{array}$ & $\begin{array}{c}\text { dry } \\
\text { weight } \\
\text { gm }\end{array}$ & $\begin{array}{c}\text { spike } \\
\text { weight } \\
\text { gm }\end{array}$ & $\begin{array}{c}\text { seed } \\
\text { weight } \\
\text { gm }\end{array}$ & $\begin{array}{c}\text { weight } \\
\text { of } 100 \\
\text { seed }\end{array}$ & HI \% \\
\hline \multirow{9}{*}{0} & 0 & 8.32 & 4.57 & 2.33 & 3.75 & 28.55 & 8.58 & 5.52 & 3.42 & 4.72 & 39.88 \\
\hline & 25 & 11.28 & 6.62 & 4.75 & 5.76 & 42.08 & 11.97 & 7.65 & 5.50 & 5.56 & 45.26 \\
\hline & 50 & 14.00 & 8.58 & 6.12 & 5.37 & 43.52 & 14.23 & 7.63 & 5.22 & 10.03 & 38.19 \\
\hline & 75 & 14.10 & 8.14 & 5.12 & 5.88 & 36.36 & 15.11 & 9.89 & 6.26 & 5.71 & 39.39 \\
\hline & 100 & 16.08 & 9.60 & 6.70 & 5.86 & 41.74 & 18.85 & 11.47 & 7.77 & 6.07 & 42.73 \\
\hline & 0 & 13.18 & 8.07 & 5.70 & 5.65 & 43.26 & 9.87 & 6.37 & 3.73 & 4.70 & 38.03 \\
\hline & 25 & 13.39 & 7.30 & 5.55 & 5.64 & 41.43 & 11.99 & 8.27 & 5.00 & 5.18 & 41.82 \\
\hline & 50 & 14.34 & 7.59 & 4.41 & 5.69 & 30.77 & 13.30 & 8.84 & 5.89 & 5.42 & 44.13 \\
\hline & 75 & 15.14 & 7.54 & 6.48 & 7.16 & 43.49 & 18.90 & 9.92 & 5.97 & 5.99 & 32.92 \\
\hline \multirow[t]{5}{*}{50} & 100 & 15.83 & 8.37 & 6.02 & 5.70 & 38.67 & 17.32 & 11.14 & 6.10 & 5.71 & 35.36 \\
\hline & 0 & 10.87 & 6.91 & 4.23 & 5.66 & 38.95 & 10.74 & 5.27 & 3.55 & 5.43 & 36.47 \\
\hline & 25 & 11.37 & 7.16 & 5.00 & 5.33 & 43.82 & 11.49 & 7.59 & 4.97 & 5.17 & 43.84 \\
\hline & 50 & 13.60 & 9.23 & 5.50 & 5.50 & 40.25 & 12.54 & 8.24 & 5.19 & 5.59 & 41.56 \\
\hline & 75 & 13.19 & 8.26 & 5.94 & 5.25 & 45.01 & 13.41 & 9.19 & 5.78 & 5.55 & 42.67 \\
\hline 100 & 100 & 14.81 & 8.70 & 6.06 & 5.86 & 40.94 & 20.09 & 10.75 & 7.49 & 6.08 & 37.81 \\
\hline
\end{tabular}

The increase of dry weight, spike weight, seed weight, weight of 100 seeds and HI may be attributed to the increase of the amounts of available elements in soil due to application of organic and mineral fertilization. Similar finding was reported by Helf. (2002), who attributed this increase to the high levels of applied fertilizers which would release high amount of available nutrients to the soil, consequently an enhancing effect on its production would be occurred. These results are in line with those reported by Parma and Sharma. (2002) and Sarwar et al. (2003). Who concluded that grain yield was significantly affected by application of synthetic fertilizer along with organic matter

\section{CONCLUSION}

The decomposition of the Jatropha curcas seed cake added to the soils as an organic fertilizer can be considered as a microbiological process, which released inorganic forms of nutrients such as nitrogen $(\mathrm{N})$ phosphorus (P) and Potassium (K). The NPK fertilizers in turn have slowly rate of release of available nutrients for plant use. The results obtained showed that J.S.C . positively affected the physical, chemical and biological indicators and consequently the soil health of both the sandy and calcareous soils. As a general comment and according to the green economy point of view, Jatropha seed cake (J.S.C.) is assured to be a very important and useful input for enhancement the soil health.

\section{REFERENCES}

Achten, W.M.J., L. Verchot, Y.J. Franken, E. Mathijs, V.P. Singh, R. Aerts, and B. Muys. 2008 Jatropha bio-diesel production and use. Biomass and Bioenergy, 32: 10631084.

Alves, M.C. 2001.Recuperação do subsolo de um Latossolo Vermelho usado para terrapleno e fundação da usina hidrelétrica de Ilha Solteira-SP. Tese (Livre Docência em Solos)-Faculdade de Engenharia-Câmpus de Ilha Solteira, Universidade Estadual Paulista. 83pp.

Canstanza, R., B.C. Norton, and B.D. Haskell. 1992. Ecosystem Health: New Goals for Environmental Management. Island Press, Washington, DC.

Casida, L.E., Jr., D.A. Klein, and T. Santoro.1964. Soil Dehydrogenase activity. Soil Sci. 98: 371 - 376. [C.A. Weaver et al (eds) Method of Soil Analysis Parts 2. Microbiological and Biochemical Properties. $3^{\text {rd }}$ Ed. Soil Sci. Soc. Am. Madison, WI.

Donlaporn, S. and S. Worapot. 2011. Toxic compound, anti nutritional factors and functional properties of protein isolated from detoxified jatropha curcas seed cake, Int. J. Mol. Sci, 12, 66-77

FAO. 1974. Physical and Chemical Methods of Soil Water Analysis. Soils Bull. No. 10. Rome. Italy.

Fortuna, A., R. Harwood, K. Kizilkaya, and E. A. Paul. 2003. Optimizing nutrient availability and potential carbon sequestration in an agroecosystem. Soil Biol. Biochem., 35: 1005-1013. 
Gonzalez, M., E. Gomez, R. Comese, M. Quesada, and M. Conti. 2010. Influence of Organic Amendments on Soil Qual-ity Potential Indicators in an Urban Horticultural Sys-tem. Bioresource Technology, 101: 8897-8901.

Gubitz, G.M., M. Mittelbach and M. Trabi.1999. Exploitation of the tropical oil seed plant Jatropha curcas L. Bioresour. Technol., 67: 73-82.

Helf, G. 2002. Progress research report (2000/2001) of the soil and water management research program, Alemaya research center, Alemaya University.

Jastrow, J.D., R.M. Miller and J. Lussenhop.1998. Contributions of interacting biological mechanisms to soil aggregate stabilization in restored prairie. Soil Biology and Biochemi. 30, 905-916.

Jones, J.r., J.B., B. Wolf, and H.A.Mills. 1991. Plant Analysis Handbook: A pactical Sampling, Preparation, Analysis and Interpretation Guide. Micro-Macro Publishing, Athens, GA.

Karlen, D.L., and D.E. Stott. 1994. A framework for evaluating physical and chemical indicators of soil quality. In: Doran, J.W., Coleman, D.C., Bezdicek, D.F., Stewart, B.A. (eds.), Defining Soil Quality for a Sustainable Environment. SSSA Special Publication No. 35, SSSA, Madison, WI, pp. 53-72.

Kemper, W. D., and R.C. Rosenau. 1986. Aggregate Stability and size distribution. In: Methods of Soil Analysis, Part 1 - Physical and Mineralogical methods. Agronomy monograph no. 9. ASA and SSSA, madison, WI. P. 425442 .

Kuzyakov, Y. 2002. Review: factors affecting rhizosphere priming effects. J. Plant Nutr. Soil Sci., 165: 382-396.

Liang, Q., H. Chen., Y. Gong., H. M. YangFan, and Y. Kuzyakov. 2014. Effects of 15 years of manure and mineral fertilizers on enzyme activities in particle-size fractions in a North China Plain soil. Europ. J. Soil Biol., 60: 112-119.

Nelson, R. R. and S.G. Winter. 1982. An Evolutionary Theory of Economic Change. Belknap Press/Harvard University Press: Cambridge.

Niklasch, H. and R. G. Joergensen. 2001. Decomposition of peat, biogenic municipal waste compost, and shrub/grass compost added in different rates to a silt loam. J. Plant Nutr. Soil Sci., 164: 365-369.

Olk, D. C. and K. G. Cassman. 1993. Reduction of potassium fixation by organic matter in vermiculitic soils. Soil Organic Matter Dynamics and Sustainability of Tropical Agriculture, pp. 307-315.

Oskoueian, E., N. Abdullah, S. Ahmad, W. Saad, and A.R. Omar. 2011. Bioactive compounds and biological activities of Jatropha curcas L. kernel meal extract. Int. J. Mol. Sci., 12: 5955-5970.

Padmavathiamma, P. K., L. Y. Li, and U. R. Kumari. 2008. An Experimental Study of Vermi-Biowaste Composting for Agricultural Soil Improvement. Bioresurce Technol., 99 (6): 1672-1681.
Page, A.L., R.H. Miller, and D.R. Keney. 1982. Methods of Soil Analysis, Part 2. Am. Soc. Agron. Madison, Wisconsin, Parma, D.K., and V. Sharma. 2002. Studies on long term application and manure on yield of maizewheat rotation and soil properties under rainfed conditions in Western-Himalayas. J. Indian Soc. Soil Sci., 50: 311-312.

Pattanayak, S. K., K. N. Mishra, K. N. Jena, and R. K. Nayak. 2001. Evaluation of green manure crops fertilized with various phosphorus sources and their effect on subsequent rice crop. J.Indian Soc. Soil Sci., 49(2): 285-291

Saetae, D., T. Kleekayai, V. Jayasena, and W.Suntornsuk. 2011. Funtional properties of protein isolate obtained from physic nut (Jatropha curcas L.) seed cake. Food Sci. Biotechnol. 20: 29-37

Sarwar, G., N. Hussain, F. Mujeeb, H. Schmeisky, and G. Hassan. 2003. Biocompost application for the improvement of soil characteristics and dry matter yield of Lolium perenne (Grass). Asian J. Plant Sci., 2 (2): 237241.

SAS, Institutes, Inc.2007. SAS Technical Report SAS/ STAT Software: Change Enhancements users Guide, Volume 2, Version 9.1.3, Fourth Edition Cary, Nc:Institute, Inc.

Scherer H.W., D.J. Metker, and G . Welp. 2011. Effect of long-term organic amendments on chemical and microbial properties of a luvisol. Plant, Soil Environ., 57: 513-518.

Singh, S., R. N. Singh, J. Prasad and B. Kumar. 2002. Effect of green manuring, FYM and biofertilizer in relation to fertilizer nitrogen on yield and major nutrient uptake by upland rice. J. Indian Soc. Soil Sci., 50 (3): 313-314.

Smiciklas, K. D., P. M. Walker, and P. M. Kelley. 2002. Utilization of Compost (Food, Paper,Landscape and Manure) in Row Crop Production. Department of Agriculture and HealthSciences, Illinois State University, USA.

Soltanpour, P.N., and A.P. Schwab.1977. A new soil test for simultaneous of macro - and micronutrients in alkaline soils. Commun. Soil Sci. Plant Anal. 3: 195 - 207.

Verma, V. K., R. K. Setia, P. L. Sharma, S. Charanjit, and A. Kumar. 2005. Pedospheric Variations in distribution of DPTA - extractable micronutrients in soils developed on different physiographic units in central parts of Punjab, India. Int. J. Agric. Biol., 7(2): 243 - 246

Walker, D. J., R. Clemente, A. Roig, and M. P. Bernal. 2003. The effects of soil amendments on heavy metal bioavailability in two contaminated Mediterranean soils. Environ. Pollut., 122: 303-312.

Watts, D.B., H.A. Torbert, Y. Feng, and S.A. Prior. 2010. Soil microbial community dynamics as influenced by composted dairy manure, soil properties, and landscape position. Soil Science, 175: 474-486. 
Yaduvanshi, N. P. S. 2001. Effect of five years of rice-wheat cropping and NPK fertilizer use with and without organic and green manures on soil properties and crop yields in a reclaimed sodic soil. J. Indian Soc. Soil Sci., 49(4): 714719.
Zupanc, V. and J. M. Zupanc. 2010. Changes in soil characteristics during landfill leachate irrigation of Populus deltoids. Waste Management, 30: 2130-2136.

\section{تأثثر اضافة تقلة بذور الجاتروفا علي خصائص صحة الأرض ونمو نبات القمح المزروع في الأراضي الرملية والجيرية}

عزه مسعود، عصام قريش، محمد رشاد، محروس قنديل

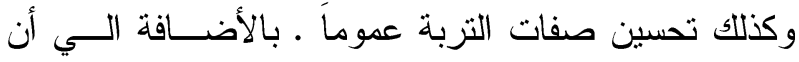

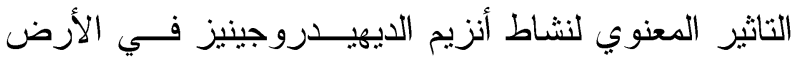

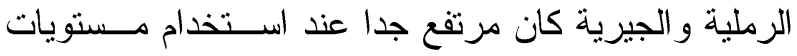
مختلفة من الأسمدة العضوية و المعدنية للأرضين. و أظهرت

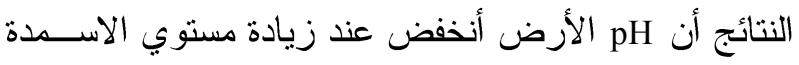

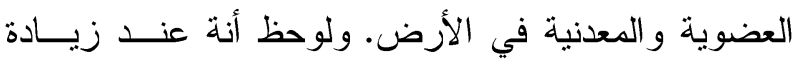

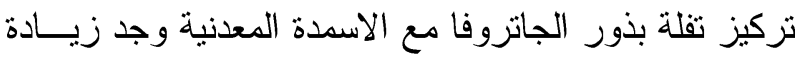

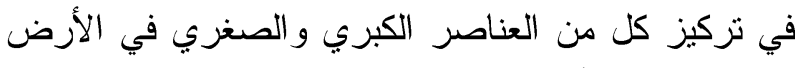

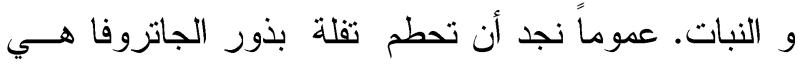

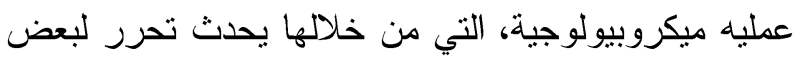

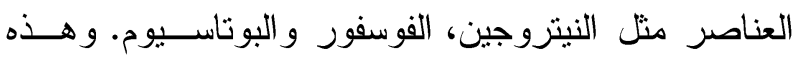
العناصر تكون متاحه لأستخدام النبات ببط. وفي النهايه نجد

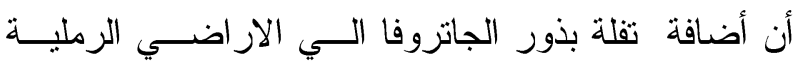

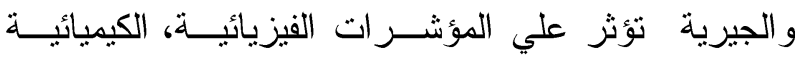
و البيولوجيه لصحة الأرض.
تفلة بذور الجانزوفا عبارة عن منتج ثانوي تم الحصول

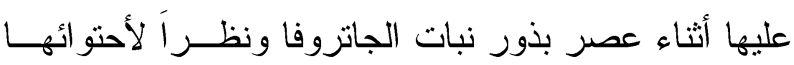

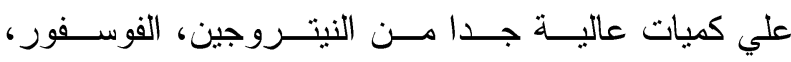

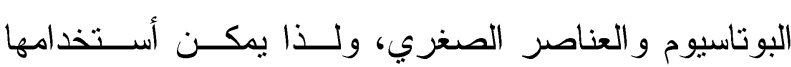

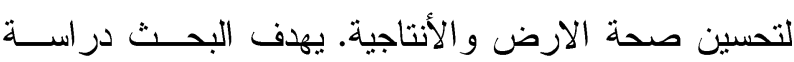

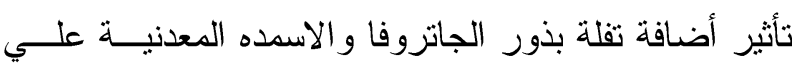

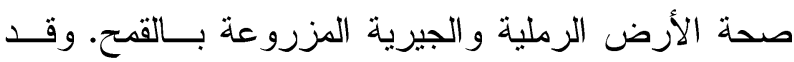

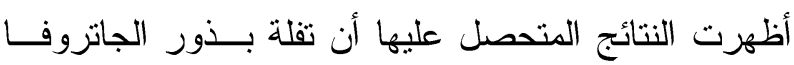

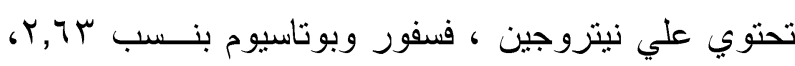

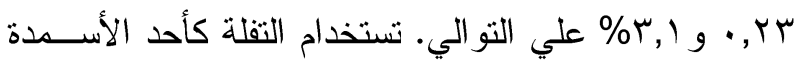

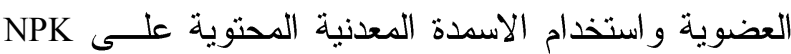

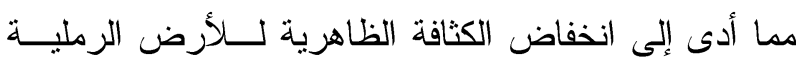

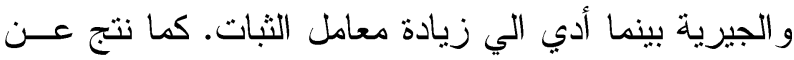
أستخدام تفلة بذور الجاتروفا كسماد عضوى بالإضافة إلـى لـى

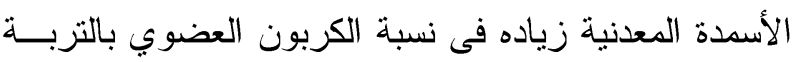

